\title{
Pediatric hydrocephalus outcomes: a review
}

\author{
Matthieu Vinchon ${ }^{1,4^{*}}$, Harold Rekate ${ }^{2}$ and Abhaya V Kulkarni ${ }^{3}$
}

\begin{abstract}
The outcome of pediatric hydrocephalus, including surgical complications, neurological sequelae and academic achievement, has been the matter of many studies. However, much uncertainty remains, regarding the very long-term and social outcome, and the determinants of complications and clinical outcome. In this paper, we review the different facets of outcome, including surgical outcome (shunt failure, infection and independence, and complications of endoscopy), clinical outcome (neurological, sensory, cognitive sequels, epilepsy), schooling and social integration. We then provide a brief review of the English-language literature and highlighting selected studies that provide information on the outcome and sequelae of pediatric hydrocephalus, and the impact of predictive variables on outcome. Mortality caused by hydrocephalus and its treatments is between 0 and $3 \%$, depending on the duration of follow-up. Shunt event-free survival (EFS) is about $70 \%$ at one year and $40 \%$ at ten years. The EFS after endoscopic third ventriculostomy (ETV) appears better but likely benefits from selection bias and long-term figures are not available. Shunt infection affects between 5 and $8 \%$ of surgeries, and 15 to 30\% of patients according to the duration of follow-up. Shunt independence can be achieved in 3 to $9 \%$ of patients, but the definition of this varies. Broad variations in the prevalence of cognitive sequelae, affecting 12 to $50 \%$ of children, and difficulties at school, affecting between 20 and 60\%, attest of disparities among studies in their clinical evaluation. Epilepsy, affecting 6 to 30\% of patients, has a serious impact on outcome. In adulthood, social integration is poor in a substantial number of patients but data are sparse. Few controlled prospective studies exist regarding hydrocephalus outcomes; in their absence, largely retrospective studies must be used to evaluate the long-term consequences of hydrocephalus and its treatments. This review aims to help to establish the current state of knowledge and to identify conflicting data and unanswered questions, in order to direct future studies.
\end{abstract}

Keywords: Pediatric hydrocephalus, Outcome, Shunt obstruction, Shunt infection, Mortality, Child-to-adult transition

\section{Review}

\section{Introduction and definition of terms}

Pediatric hydrocephalus $(\mathrm{HC})$ is a surgical disease. If left untreated, most cases are lethal [1]. With present-day standard of care, most patients with $\mathrm{HC}$ will survive; however, death from hydrocephalus still exists [2,3], and the sequelae among long-term survivors are frequent and often severe [4]. Because of the multiplicity of causes of hydrocephalus, associated diseases, complications of treatment, and the inherent complexity of the patient population, reliable data on outcomes are difficult to obtain. The outcome of hydrocephalic patients has been the subject of many studies, some presenting conflicting results, and many focusing on a limited view

\footnotetext{
* Correspondence: matthieu.vinchon@chru-lille.fr

'Department of Pediatric Neurosurgery, Lille University Hospital, Lille, France ${ }^{4}$ Department of Pediatric Neurosurgery, Hôpital Roger Salengro, CHRU de Lille, Lille Cedex 59037, France

Full list of author information is available at the end of the article
}

of this vast field. Among the questions asked by legitimately anxious parents, and sometimes by the patient himself, are: what are the risks of complication of surgery? What are the risks that my child dies of this disease? What are the sequels that my child might suffer? We shall therefore categorize hydrocephalus outcomes under the following broad headings: surgical outcome (shunt half-life, rate of shunt malfunction, rate of infection, and the issue of shunt-independence) and complications of endoscopy; mortality (shunt-related as well as related to other causes); morbidity (cognition, motor system, vision, epilepsy, neuroendocrine problems and fertility, chronic headache); and functional social outcome (schooling, social integration, marital status). The present review aims to discuss these different facets of outcome in pediatric hydrocephalus, review the available literature on the topic and identify the gaps in our present knowledge. We will try to identify predictive

\section{Biomed Central}


factors for outcome and to define what are the medical needs for this population in the future, especially when they become adults, how to evaluate them, and which guidelines can be proposed for follow-up.

\section{Problems and controversies in outcome definitions Surgical outcome}

Shunt failure can be aseptic (malfunction) or septic (shunt infection). Malfunction includes obstruction, overdrainage, underdrainage, and occult shunt failure (including the need for elective revision for tube lengthening). Its occurrence being duration-dependent, the incidence of malfunction is generally expressed as actuarial survival. Reoperation, although potentially subject to surgeon bias, can be seen as the best criterion to define malfunction, as it is a binary variable and a dated event, allowing survival analysis. However, some cases of malfunction can be dealt with without surgery, e.g., overdrainage that is solved by valve adjustment or one that is simply accepted by the patient as a minor nuisance. On the other hand, occult shunt failure (e.g., a broken shunt in an asymptomatic patient) is sometimes accepted with little scientific evidence, as an indication that the patient has become shunt-independent [5]. A more rigorous approach to shunt independence is advocated below.

Shunt infection has been defined differently depending on the goal of the study: a positive culture is an adequate criterion for bacteriological studies; clinical symptoms with positive culture and or pleocytosis (Odio's criteria) [6] is a criterion more adapted to clinical studies, however cultures can be falsely positive as well as falsely negative. Restrictive definitions excluding cases with negative cultures carry the risk of underestimating the real problem. Studies on surgical outcome should adopt a surgery-based criterion: a medical diagnosis based on clinical findings and/or biology, leading to reoperation or death [7-9]. This definition, based on the assumption that infection cannot be cured without reoperation, generally shunt removal, has the advantage of a binary and dated event allowing actuarial analysis [8]. More detail on the type of infection can be provided using the classification proposed by the CDC [10], rating the infection as incisional (skin and dermis), deep-incisional (subcutaneous tissues), and organ/space infection. The definition of infection by the CDC also emphasizes the importance of clinical judgment: "Diagnosis of an organ/space (surgical site infection) by a surgeon or attending physician" [10]. Although postoperative infection is generally defined as occurring with one month of surgery, the rate of infection should also be evaluated over a longer term, since infection can occasionally occur several years after surgery. Survival analysis should be used in order to take into account the impact of late shunt contamination [9].
Different types of infection rates can be calculated and should be clearly specified: by operation (number of operations complicated by infection); by patient (number of patients in a series having had at least one septic episode); by surgeon (number of septic complications among the total number of patients operated by a given surgeon) [11], or by hospital [12]; and actuarial incidence $[8,9]$. Rates by surgeon or by hospital can be difficult to ascertain because patients are often operated by different surgeons or in different hospitals [13].

Shunt independence is defined as the successful removal or ligature of all shunts, but it does not always mean that the hydrocephalus is "cured". It includes patients with successful secondary endoscopic treatment $[14,15]$, but who, nevertheless, remain reliant on internal CSF diversion; patients who become shunt independent spontaneously [16]; and patients who undergo progressive upgrading of an adjustable valve, or planned removal of their shunt, which should be performed with great caution and patience. Some delay after shunt removal is necessary to assert that the patient is truly shuntindependent; how long the follow-up should be is undetermined, but delayed deterioration has been reported several years after apparently successful shunt removal [17]. It should be emphasized that, whereas symptomatic shunt failure proves shunt-dependence, the reverse is not true. Contrary to some authors who stated that the absence of shunt failure during more than 18 years attests to shunt-independence [18], some patients can present with their first malfunction more than 20 years after shunt insertion: in a series of 456 patients having reached adulthood, 22 patients presented with their first shunt failure after the age of 20 , with a fatal outcome in one case [4].

Complications of endoscopy include failure (obstruction), infection and surgical morbidity [19]. Failure of endoscopic third ventriculocisternostomy (ETV) can be defined as primary (failure to achieve an efficient stoma) or secondary (obstruction of a previously patent stoma). In studies comparing endoscopy and shunting, failure of the endoscopic technique has also been defined as the need to implant a shunt, but this definition excludes failed cases that were treated by redo ETV [20,21]. Evaluation of the primary failure rate should be based on a clear statement of the intent to treat. The rate of secondary failure is duration dependant, and actuarial survival studies are necessary [22,23]. In spite of a growing literature, the long-term actuarial survival of ETV is still poorly documented. For the comparison between ETV and shunting, important confounders, like age and origin of hydrocephalus need to be accounted for with sophisticated statistical methods [24], although this still falls short of the gold-standard of randomization. 


\section{Mortality}

It is important to determine whether or not mortality is related to hydrocephalus and its treatment. When death occurs immediately after surgery, or of documented shunt failure, shunt-related mortality is beyond doubt. Shunted patients can also die of associated conditions, e.g., brain tumor or metabolic disease, unrelated intercurrent events, e.g., accidental trauma, or related ailment, e.g., malnutrition or infection in a severely debilitated patient. All of these identified causes of death should be considered as shunt-unrelated. There remain grey areas in which the cause of death can be multiple or be totally unexplained. In a shunted patient, the occasional sudden death can often be retrospectively ascribed to shunt complication [25]. Based on these data, sudden unexpected death in a shunted patient should be considered as shunt-related by default, similar to the SUDEP in epilepsy (Sudden Unexpected Death of the Epileptic Patient).

\section{Morbidity}

This term covers all health-related limitations to living a normal life. It is evaluated quantitatively by outcome and quality of life scales, and by the presence or absence of different sequela (binary variables). Overall functional outcome can be quantified using established generic scales like the Barthel index (10 variables graded 1 to 10) [26], Karnofsky scale (11 grades), and the Glasgow Outcome Scale (GOS, 5 grades) [4]; historically, a fivetier grading system precursory of the GOS had already been proposed by Laurence in 1962 [1], and Resch also used a scale very similar to the GOS [27]. The GOS following the WFNS $(1=$ normal, $5=$ dead $)$ is relatively crude but can easily be calculated in retrospective studies, is not influenced by age, and allows comparisons with other neurosurgical diseases [28]. We found no study on pediatric hydrocephalus using the Rankin 7grades scale, although this is widely used in adult studies. The Barthel index is a highly detailed quantitative outcome measure, but we found it used in no study on pediatric hydrocephalus. Quality of life can be evaluated quantitatively with SF36 scale [26], which requires a prospective evaluation of patients. Recently, the Hydrocephalus Outcome Questionnaire (HOQ), a disease-specific quality of life scale, has been proposed for pediatric hydrocephalus by Kulkarni et al. [29], translated in several languages, and validated by other teams [30]. The Barthel Index, SF36 and HOQ are highly detailed quantitative scores, which require prospective collection of data and a fairly heavy logistic organization.

In hydrocephalus, the most important specific functional concerns are:

- Impaired mobility and ambulation (e.g., cerebral palsy)

- Impaired cognition (mental delay, behavior) [31-33]
- Sensory deficits (vision, hearing) [34-36]

- Endocrine dysfunction (growth, puberty, weight balance, fertility) $[4,37,38]$

- Epilepsy $[8,39]$

- Depression [37]

- Pain (chronic headache) [40].

All these variables are often rated dichotomously as present or absent (binary variables) or measured quantitatively, following specific scales. In particular, cognition can be evaluated by different tests, adapted to age: Wechsler preschool, WISC 3, WISC 4 [31,41], Gesell, Bayley developmental scale for infants [33,34,39], and Brunet-Lezine test developmental test for infants [39]. These tests are useful to determine a neuropsychological profile and compare hydrocephalic patients with others. However, many of these tests cannot be performed in severely delayed patients, introducing an important selection bias [42]. Studies reporting the results of tests are conflicting: classically, Dennis et al. found a predominant deficiency of performance versus verbal IQ [32], while more recent studies did not confirm their results $[31,41]$. Moreover, these tests often underestimate deficits in social competence [4]. School difficulties can be the result of a range of different deficits, cognitive being the most prominent, as well as frequent absences from school due to repeated hospital stays. Schooling is thus not a faithful reflection of pure cognitive handicap. Schooling is generally grossly rated as normal or delayed [26] or can be given a little more detail, such as: normal, normal with help, delayed, special school for mentally handicapped, and no schooling at all [4].

How a pediatric patient functions in society is perhaps the ultimate test of outcome. This includes professional/ career achievement, achievement of intimate relationships, and community integration. It should be evaluated by comparison with the expected social outcomes for peers. In many cases the social outcome is poorer than would be expected based on cognitive deficits and school performance, illustrating a "hidden handicap" [4]. Employment status can be categorized as full employment (on the competitive labor market or independent mothers at home), unemployed, sheltered/assisted employment, and handicapped (at home or in special institution).

\section{Information gained through existing publications Methods}

In order to survey the current state of the outcome literature in pediatric hydrocephalus, a Pubmed search was conducted using "pediatric hydrocephalus" and "clinical outcome" as key words, yielding 206 citations. After selecting clinical series, searching among related citations, and adding some publications on specific 
topics, the survey consisted of 122 references. These studies included prospective studies, retrospective studies, and cross-sectional surveys. We also identified long-term series, for which patients were followed until late childhood/adulthood. The following data were extracted: the population studied (age and cause of hydrocephalus), duration of follow-up, the incidence of shunt malfunction and infection, the mortality and morbidity, the functional outcome (schooling, occupation, social integration), and in rare studies, the medical resources available.

\section{Results}

We found only six prospective studies [29,30,34,43-45] and these had a mean follow-up of 20 months [34], 5 years [43], and 9.9 years [29]. In one study, follow-up was terminated when the study endpoint (shunt failure) was reached [46]. Retrospective studies represent the bulk of medical literature on hydrocephalus outcome. The value of these studies rests in the unselected nature of the patient sample, homogeneity of medical management, and long duration of follow-up. Four studies reported on the long-term outcome of patients beyond 18 years $[4,26,37,47]$. Several studies were based on the voluntary participation of patients [37,47-49]. The willingness to participate in a study, often through the channel of patient advocacy groups, introduces an important selection bias [42]. In addition, some studies presented the neuropsychological evaluation of selected patients $[33,41]$; their purpose was to define a profile in the hydrocephalus population, rather than an overall view of the outcome. Finally, other studies were based on data stored in registries $[12,50]$, and give an epidemiological rather than a clinical perspective.

To summarize the data from an abundant but heterogeneous and unformatted literature, we constructed two tables. Table 1 is aimed at establishing the incidence and prevalence of the different elements of outcome detailed above, with figures from the literature, and comments on possible bias of the cited studies.

Table 2 aims at establishing the relationship between predictive variables (including those related to the patient, surgery, and medical resources) and dependent variable (outcome). Four variables (epilepsy, shunt obstruction, shunt infection and endoscopy) are listed both as predictive and as dependent variables. The combination of these variables with themselves is often meaningless (the predictive and dependent variables are collinear), however shunt failure has in itself a definite impact on the risk of further shunt failure. Table 2 shows that there is a broad consensus on some items, such as the association between young age at surgery and shunt failure $[8,37,61,62]$ and shunt infection [7-9,61]. There is a more limited consensus on other items, such as the association between shunt infection and shuntrelated mortality $[9,58]$. For other associations, we found data from only one study (e.g., the correlation between prematurity and quality of life [29]). Other associations had conflicting results (e.g., between shunt obstruction and epilepsy, which was significant according to Bourgeois et al. [39], but not Piatt and Carlson [60]). Finally, for several of these associations, we found no documentation in literature (e.g., between epilepsy and social integration). Although a more extensive literature search may fill some of these gaps, there is obviously a great need for more clinical research.

\section{Analysis of information and identification of information gaps}

(How can we evaluate the hydrocephalic patient and who does the evaluation?)

\section{Self-evaluation by the patient}

It is now recognized that the patients' perspective on their own outcomes is probably the most relevant. The National Institutes of Health has, in fact, made this a strong program focus under Patient-Reported Outcomes Measurement Information System (https://commonfund. nih.gov/promis/). In pediatric hydrocephalus, these outcomes are often completed by proxy (usually parents), because most young children under 10-12 years are not capable of meaningfully answering questions about their health. Health in this context is recognized to be multidimensional and cuts across broad domains of physical health, social-emotional health, and cognitive health. Specific measures of each of these domains exist, with neuropsychological testing being one of the most commonly used. Taken together, these domains comprise the overall concept of health. Quality of life (QOL) is a specific measure of health, taken from the perspective of how the patients feel they are doing in these domains. It can be argued that the ultimate goal of our management is to optimize QOL, since it is the final common measure of outcome. For example, improvements in shunt technology resulting in fewer admissions for shunt failure should be manifest in improved QOL for the patient, as should physiologically optimizing CSF drainage so as to improve intellectual function. While the immediate effects of these could be measured in terms of reduced days of admission or higher neuropsychological test scores, the ultimate test of their impact is the effect they have in improving QOL. Generic measures of overall health and QOL in children include the PedsQL, the Child Health Questionnaire, and the Health Utilities Index, while the Hydrocephalus Outcome Questionnaire is an example of a disease-specific measure [78]. 
Table 1 Incidence of different complications and prevalence of the different types of morbidity according to literature

\begin{tabular}{|c|c|c|c|}
\hline \multicolumn{2}{|c|}{ Complications and morbidity } & \multirow{2}{*}{$\begin{array}{l}\text { Data in literature } \\
2.7 \text { at } 24.2 \text { years [4] } 4.2 \text { at } \\
20 \text { years [26] } 2.7 \text { at } 17 \text { years [49] }\end{array}$} & \multirow{2}{*}{$\begin{array}{l}\text { Comment on biases } \\
\text { duration-dependent; rates of } \\
\text { revision also reflects the closeness of follow-up }\end{array}$} \\
\hline shunt obstruction & $\begin{array}{l}\text { number of shunt } \\
\text { revisions per patient }\end{array}$ & & \\
\hline & Event-Free Survival at 1 year & $70 \%[8,51] 62 \%[46] 80 \%[4]$ & $\begin{array}{l}\text { depends on the age at insertion and the } \\
\text { number of prematures shunted }\end{array}$ \\
\hline & Event-Free Survival at 10 year & $35 \%[51], 48 \%[4]$ & few data on the very long term \\
\hline Endoscopy failure rate & Event-Free Survival at 5 years & $62 \%[22] 45 \%[23]$ & few data on the very long term \\
\hline \multirow[t]{4}{*}{ shunt infection } & per surgery & $0.17 \%[52] 7.9 \%[11] 8.4 \%[46]$ & $\begin{array}{l}\text { depends on definition criteria, selection of } \\
\text { patients and duration of follow-up }\end{array}$ \\
\hline & per patient (long term) & $15.6 \%[4] 37.5 \%[37]$ & depends on duration of follow-up \\
\hline & $\begin{array}{l}\text { per surgeon } \\
\text { (range within a team) }\end{array}$ & $\begin{array}{l}5.2-12.2 \%[9] 7-9.4 \%[53] \\
6.1-11.7 \%[11]\end{array}$ & $\begin{array}{l}\text { significant differences between surgeons } \\
\text { [53]; NS[9,11] }\end{array}$ \\
\hline & actuarial incidence & $\begin{array}{l}8.5 \% \text { at } 1 \text { year }[8] 20.3 \% \text { at } \\
10 \text { years [9] }\end{array}$ & very few data on long-term incidence \\
\hline \multirow[t]{2}{*}{ shunt independence } & overall & $3.2 \%[54] 9 \%[55]$ & $\begin{array}{l}\text { depends on etiology of hydrocephalus and } \\
\text { eargeness to remove the shunt }\end{array}$ \\
\hline & $\begin{array}{l}\text { successful endoscopy } \\
\text { when shunt malfunction }\end{array}$ & $77 \%$ of attempts [15] 64\% [14] & reflects selection of patients \\
\hline \multirow[t]{3}{*}{ Mortality } & overall & $1.22[56] 14.6 \%[57]$ & depends whether tumors are included or not \\
\hline & non-tumoral mortality & $8.6 \%[58] 13.7 \%[49]$ & $\begin{array}{l}\text { depends on duration of follow-up and } \\
\text { intercurrent events in debilitated patients }\end{array}$ \\
\hline & shunt-related & 0 [48] 2.9\% [26] 3.65\% [57] & $\begin{array}{l}\text { depends on duration of follow-up; impact of } \\
\text { staff and patient education }\end{array}$ \\
\hline \multirow[t]{9}{*}{ Morbidity } & motor handicap & $30 \%[30] 34.2 \%$ [56] 60\% [36] & series with spina bifida \\
\hline & low IQ & $12.5 \%[47] 54.2 \%[48]$ & selection bias for testing \\
\hline & normal schooling & $38 \%[43] 30 \%[36] 79 \%[26]$ & depends on tolerance of schooling system \\
\hline & no schooling & $5.5 \%[4] 9 \%[30] 9 \%[36]$ & depends on tolerance of schooling system \\
\hline & visual & $25 \%[36] 33 \%[59] 83 \%$ [35] & depends on how thoroughly examined \\
\hline & pregnancy & $14.5 \%[4] 20.6 \%[37]$ & impact of early age of shunting \\
\hline & epilepsy & $\begin{array}{l}\text { 2\%/year [60] 6.5\% [4] 14\% } \\
\text { [30] } 25 \% \text { [57] 30\% [36] 32\% [39] }\end{array}$ & $\begin{array}{l}\text { associated with severe initial disease } \\
\text { and poor outcome }\end{array}$ \\
\hline & depression & $43.2 \%[37]$ & $\begin{array}{l}\text { may be biased by selection } \\
\text { (self reported morbidity) }\end{array}$ \\
\hline & headache & $8 \%[4] 44 \%[40]$ & depends on age \\
\hline \multirow[t]{3}{*}{ social integration } & $\begin{array}{l}\text { normal job } \\
\text { (competitive labor market) }\end{array}$ & $33.3 \%[4] 56 \%[5]$ & bias linked with protracted follow-up \\
\hline & sheltered job & $23 \%[4,26]$ & depends on proactive welfare system \\
\hline & partner & $6 \%[5] 22 \%[26] 37 \%[37]$ & $\begin{array}{l}\text { selection bias: studies based on } \\
\text { voluntary participation }\end{array}$ \\
\hline
\end{tabular}

\section{Evaluation by clinicians}

The literature review found mostly retrospective studies. Evidence-based medicine would require more prospective studies, however these studies have been difficult to set in place and sometimes disappointing in their results and interpretation $[43,46]$. There are several acknowledged barriers to randomized trials in pediatric hydrocephalus including: a relatively small number of patients, a large variety of available shunt materials and techniques, heterogeneous and often tradition-based practices, and the important questions to be answered (patient development, academic achievement, social integration) require very long-term follow-up. Despite these barriers, we must continue to strive for randomized trials, where appropriate, and to also take steps to make future retrospective and non-randomized prospective studies more useful. For example, scientific societies and journals should encourage the standardized use of evaluation tools and analytic techniques (e.g., actuarial survival rates, QOL scales).

\section{What are the determinants of outcome?}

The voids in Table 2 show that there is room for clinical research on the determinants of hydrocephalus outcome, 
Table 2 Association between factors pertaining to the patient, treatments and medical resources (predictive variables) and surgical and clinical outcomes

\section{(dependent variables)}

\begin{tabular}{|c|c|c|c|c|c|c|c|c|c|c|}
\hline $\begin{array}{cc}\text { Predictive } & \text { Dependent } \\
\text { variable } & \text { variable }\end{array}$ & Shunt failure & Shunt infection & $\begin{array}{l}\text { Hydrocephalus- } \\
\text { related } \\
\text { mortality } \\
\end{array}$ & $\begin{array}{l}\text { Endoscopy } \\
\text { failure }\end{array}$ & $\begin{array}{l}\text { Neurological } \\
\text { deficit }\end{array}$ & Epilepsy & $\begin{array}{l}\text { Cognitive } \\
\text { impairment }\end{array}$ & $\begin{array}{l}\text { Difficulties } \\
\text { at school }\end{array}$ & QOL & $\begin{array}{c}\text { Social } \\
\text { insertion }\end{array}$ \\
\hline $\begin{array}{l}\text { Young age } \\
\text { at surgery }\end{array}$ & higher $[8,37,61,62]$ & higher $[7-9,61]$ & higher $[50,63]$ & higher $[21,64]$ & higher [31] & $\begin{array}{l}\text { higher [31] } \\
\text { NS [60] }\end{array}$ & higher $[31,44]$ & higher [44] & $\begin{array}{l}\text { lower } \\
{[29,30,37,44]}\end{array}$ & lower [37] \\
\hline Prematurity & higher [62,65-68] & higher [7,66-68] & $\begin{array}{l}\text { higher [27] } \\
\text { NS [67] } \\
\text { lower [44,50] }\end{array}$ & higher [69] & $\begin{array}{l}\text { higher } \\
{[27,44,68]}\end{array}$ & higher [39] & higher $[27,68]$ & $\begin{array}{l}\text { higher [44] } \\
\text { NS [9] }\end{array}$ & lower [29] & $\begin{array}{l}\text { no data } \\
\text { found }\end{array}$ \\
\hline $\begin{array}{l}\text { Post-meningitis } \\
\text { hydrocephalus }\end{array}$ & Higher $[56,62,70]$ & NS $[7,9]$ & higher [71] & $\begin{array}{l}\text { higher [20] } \\
\text { NS [72] }\end{array}$ & lower [57] & higher $[30,39,56]$ & higher $[4,40,56]$ & higher $[5,9,61]$ & lower $[4,30]$ & lower [4] \\
\hline $\begin{array}{l}\text { ventricular } \\
\text { hemorrhage }\end{array}$ & $\begin{array}{l}\text { higher }[8,62,70] \\
\text { NS }[61]\end{array}$ & $\begin{array}{l}\text { higher }[73] \\
\text { NS }[7,9]\end{array}$ & $\begin{array}{l}\text { lower [4] } \\
\text { higher [63] }\end{array}$ & higher $[20,69]$ & higher $[34,57]$ & higher $[39,56,57]$ & $\begin{array}{l}\text { higher } \\
{[30,34,44,57]}\end{array}$ & $\begin{array}{l}\text { higher }[5,61] \\
\text { NS }[9]\end{array}$ & $\begin{array}{l}\text { lower [30] } \\
\text { higher [4] }\end{array}$ & lower [4] \\
\hline spina bifida & higher $[62,74]$ & $\begin{array}{l}\text { higher [74] } \\
\text { NS [7] }\end{array}$ & higher $[3,50,58,74]$ & higher [18,23] & higher $[56,57]$ & lower $[39,57]$ & lower $[36,57]$ & $\begin{array}{l}\text { Lower }[49] \\
\text { higher }[9]\end{array}$ & lower $[4,30]$ & lower [4] \\
\hline shunt obstruction & $\begin{array}{l}\text { risk of recurrent } \\
\text { revisions }[8,62,70]\end{array}$ & $\begin{array}{l}\text { risk increases } \\
\text { with recurrent } \\
\text { revisions [70] }\end{array}$ & main cause [63] & higher $[22,23,75]$ & $\begin{array}{l}\text { higher [44] } \\
\text { NS [57] }\end{array}$ & $\begin{array}{l}\text { higher [39] } \\
\text { NS [60] }\end{array}$ & $\begin{array}{l}\text { higher }[57,76] \\
\text { NS }[41,47,49]\end{array}$ & $\begin{array}{l}\text { Higher [76,77] } \\
\text { NS [61] }\end{array}$ & lower [29] & $\begin{array}{l}\text { no data } \\
\text { found }\end{array}$ \\
\hline shunt infection & (1) & (1) & higher $[9,58]$ & higher [22] & higher [30] & $\begin{array}{l}\text { higher }[9,39] \\
\text { NS }[60]\end{array}$ & higher $[9,57]$ & higher [9] & lower $[9,78]$ & $\begin{array}{l}\text { no data } \\
\text { found }\end{array}$ \\
\hline endoscopy & lower $[19,24]$ & lower $[19,79]$ & $\begin{array}{l}\text { lower [23] } \\
\text { NS [73] }\end{array}$ & (1) & no data found & lower $[39,80]$ & NS [79] & no data found & $\begin{array}{l}\text { better [73] } \\
\text { NS [79] }\end{array}$ & $\begin{array}{l}\text { no data } \\
\text { found }\end{array}$ \\
\hline epilepsy & $\begin{array}{l}\text { higher in } \\
\text { infants [60] }\end{array}$ & no data found & no data found & no data found & no data found & (1) & $\begin{array}{l}\text { higher } \\
{[36,39,56,81]}\end{array}$ & higher [39] & lower $[29,30]$ & $\begin{array}{l}\text { no data } \\
\text { found }\end{array}$ \\
\hline local resources & $\begin{array}{l}\text { high volume of } \\
\text { surgery: } \\
\text { lower [12] }\end{array}$ & $\begin{array}{l}\text { high volume of } \\
\text { surgery: } \\
\text { lower [12] }\end{array}$ & $\begin{array}{l}\text { high volume: } \\
\text { lower [12] } \\
\text { geographic } \\
\text { distance: } \\
\text { higher [63] }\end{array}$ & no data found & no data found & no data found & no data found & no data found & $\begin{array}{l}\text { geographic } \\
\text { distance: } \\
\text { lower [29] }\end{array}$ & $\begin{array}{l}\text { no data } \\
\text { found }\end{array}$ \\
\hline
\end{tabular}

Because they are both causes and consequences, shunt obstruction, shunt infection and epilepsy are indicated both as predictive and dependent variables.

(1): these correlations are not documented because meaningless (collinear variables); however, shunt obstruction has a documented impact on the risk of recurrent shunt failure [8,62,70].

The voids in this table indicate that there is space for clinical research on hydrocephalus outcome, especially on the very-long term outcome. QOL: quality of life. 
especially very-long term outcome. This table can also be expanded by adding other variables not listed above. Among predictive variables not listed because of the paucity of data available, prenatal hydrocephalus is of particular interest, because its predicted outcome is an important element of decision-making for antenatal treatment and/or interruption. Other outcome variables like vision, endocrine sequelae and fertility, are also of importance for the daily life of these patients, and could be anticipated or prevented with better knowledge of their determinants.

\section{How can shunt-related mortality and morbidity be reduced?}

Table 1 lists a long litany of sequelae and complications, which plague the patients' life and sometimes make it shorter. Having identified these problems, the next step is to find ways to fix them. Prevention of morbidity requires early diagnosis and treatment of hydrocephalus, but this is often beyond the control of neurosurgeons. The neurosurgeons' undisputed role is to avoid complications of treatment. As Oakes stated: "Lowering the infection rate and extending the interval between shunt revisions are appropriate and admirable goals. Helping these patients achieve a more useful life is ideal" [42]. Reducing the incidence of shunt infection requires a number of measures before, during and after surgery $[7,10]$, and applying these measures rigorously has proved effective [52]. Analyzing all possible types of shunt failure, Sainte-Rose et al. defined the characteristics of the ideal shunt design [51]. However, prospective studies have failed to assert the superiority of one shunt design over another $[43,45,46]$. Surgery for shunt failure diagnosed at a pre-symptomatic stage has also been advocated as a way to prevent catastrophic shunt blockage and lower the complication rate of shunt revision [82]. Ultimately, the best way to avoid shunt complications might be to employ endoscopy whenever possible, seizing the opportunity when the patient presents with a blocked shunt $[14,15]$. How often this opportunity translates into a durable benefit for the patient remains to be evaluated [75]. Monitoring the rate of septic and aseptic complications should be part of each neurosurgeon's duties. Compulsory national registries, like the one created in the UK could become a standard [83]. It would be preferable, however, that the motivation for this comes from clinicians, rather than be imposed by institutional authority.

Another approach to these problems could be through re-organization of healthcare delivery. In-hospital mortality and complications after shunt operation have been shown to be significantly lower in high-volume hospitals, compared to hospitals with a smaller volume of activity [12]. While this would seem to support centralization of care to larger centers, this collides with another important tenet: fast referral in case of emergency [63]. Long distances can also be an impediment to clinical follow-up and Kulkarni et al. found a correlation between geographic distance and a lower QOL score [29]. On the other hand, high volume and clinical experience can foster the creation of ad hoc protocols for emergency management [84]. A non-centralized approach would require adequate training and teaching of nonspecialist neurosurgeons and the organization of backup support networks. A side benefit of the latter solution would be a smoother transition to adult care when the child grows up.

\section{What are the ideal modalities of follow-up for shunted patients?}

The follow-up of hydrocephalic patients is essential, in order to diagnose and manage long-term complications early and to evaluate the results of treatments. There is no consensus regarding the optimal mode of this followup. While most authors agree that it falls to the neurosurgeon [85,86], some authors suggest that these patients could be followed by a general practitioner or a pediatrician [87]. As detailed above, however, the complexity and rarity of the condition in general practice often makes the follow-up of these patients a specialist's role. Standards have yet to be established regarding the frequency of visits and imaging. Several authors advise a clinic visit every second year $[82,88]$. Fundoscopy is innocuous but has not proved its usefulness for the diagnosis of shunt failure in asymptomatic patients, and is often falsely negative. The role of brain imaging is much debated. It is important to obtain a baseline cerebral image, to provide adequate comparison when suspicion of shunt malfunction arises [18]. This imaging should be performed at least 6 months after shunt insertion or revision in order to show the effect of shunting [45], because it could take up to 14 months for ventricle size to plateau [89]. It appears reasonable to keep X-ray imaging to a minimum and MRI should be preferred to CT whenever possible [90]. MRI poses a different problem in infants who require sedation, even with specific quick sequences [91]. The practice of routine shunt series is based on the possibility of asymptomatic disruption or migration preceding overt shunt malfunction [82], and its yield has been evaluated at 1.4\% [92]. Whether such a rate justifies routine shunt series or not is debatable. Up to now, no alternative has been found to explore the physical integrity of the shunt and avoid X-rays.

\section{What are the ideal modalities of follow-up after endoscopic surgery?}

When ETV became widespread, it was considered, unlike shunts, as a minimally invasive and definitive cure for hydrocephalus. It is now recognized that complications 
also occur after ETV, including obstruction, infection, CSF leakage, intraventricular hemorrhage, and damage to the tuber cinereum with diabetes insipidus [21,75]. Cases of secondary occlusion of the ventriculostomy with delayed catastrophic deterioration are documented [93], however, estimations of hydrocephalus-related mortality after ETV are lacking. There is no consensus over the modalities of follow-up after ETV. Systematic clinical follow-up appears no less necessary after ETV than for shunted patients. However, the duration of this follow-up is not settled: "At what point follow up can be discontinued is not known" [93]. The need for systematic MRI is debated, some authors considering it unnecessary [94] while the majority recommends its routine use $[19,93]$. In addition to clinical follow-up, education of the patient and caregivers is mandatory [93]. Long-term clinical follow-up studies are necessary to document the surgical and clinical outcome after ETV.

\section{How cost-efficient is the management of pediatric hydrocephalus?}

The treatment of hydrocephalus has measureable economic consequences, as does the outcome of such treatment. Economic costs are born by the patient/family, the hospital, the insurer, and society. It is no longer considered beyond the scope of physicians to consider these economic costs in making treatment decisions. In the face of finite healthcare resources, it is our duty to provide the best care, but to also do so in the most economically efficient manner possible. Health care economics is complicated, however, and treatment that might seem cheaper from the perspective of one party (e.g. the insurer), might be more costly to another (e.g., the patient/family).

\section{Organizing the transition from child to adult care}

Like many pediatric diseases, hydrocephalus begins during childhood and continues during adulthood. The yearly incidence of neonatal hydrocephalus was estimated as 2000 cases in the US [37]; with a mortality of $18.1 \%$ during the last four decades [4], the expected population of hydrocephalic patients reaching the age of 20 years should be over 1638 patients every year for the US. The transition that occurs when young patients grow into adults is a complex process, occurring over years, and is often met with sudden changes in health care environment and personnel for these patients. This transition should be anticipated with progressive education of the patient and his family [95]. No universal recipe exists for the management of this transition; the factors involved include the patient's specific health issues, their ability to cope with complex problems, their ability to independently navigate the healthcare system, the availability of familial support, and the accessibility of healthcare resources. Once transition has occurred, it remains important to measure outcomes relevant to the adult patient, such as achievement in societallyappropriate adult roles (higher education, employment, family, etc.). Knowledge about these outcomes and evidence to improve them is relatively sparse in our literature

\section{Conclusions}

The challenges of measuring and improving outcome of all types in pediatric hydrocephalus have been outlined in this paper. These challenges can only be met with a cooperative, systematic approach that emphasizes methodologically-strong research with long-term followup of a broad range of outcomes, all of which are important to patients with hydrocephalus.

\section{Competing interests}

The authors do not have anything to disclose, including commercial, financial, or other associations, that pose a conflict of interest in connection with the submitted article.

\section{Authors' contributions}

MV: was responsible for the collection of data, interpretation of the data, and for the drafting and editing of the document. HR and AK were responsible for the drafting and editing of the document. All authors read and approved the final manuscript.

\section{Acknowledgement}

The expenses for publication in Fluids and barriers of the CNS were covered by the International society for hydrocephalus and CSF disorders who commissioned the study for a hydrocephalus thematic issue.

\section{Author details}

'Department of Pediatric Neurosurgery, Lille University Hospital, Lille, France. ${ }^{2}$ Chiari institute, New York, NY, USA. ${ }^{3}$ Division of Neurosurgery, Hospital for Sick Children, Toronto, ON, Canada. ${ }^{4}$ Department of Pediatric Neurosurgery, Hôpital Roger Salengro, CHRU de Lille, Lille Cedex 59037, France.

Received: 3 May 2012 Accepted: 11 July 2012

Published: 27 August 2012

\section{References}

1. Laurence KM, Coates S: The natural history of hydrocephalus. Detailed analysis of 182 unoperated cases. Arch Dis Child 1962, 37:345-362.

2. Acakpo-Satchivi L, Shannon CN, Tubbs RS, Wellons JC 3rd, Blount JP, Iskandar BJ, Oakes WJ: Death in shunted hydrocephalic children: a follow-up study. Childs Nerv Syst 2008, 24:197-201.

3. Iskandar BJ, Tubbs S, Mapstone TB, Grabb PA, Bartolucci AA, Oakes WJ: Death in shunted hydrocephalic children in the 1990s. Pediatr Neurosurg 1998, 28:173-176.

4. Vinchon M, Baroncini M, Delestret I: Adult outcome of pediatric hydrocephalus. Childs Nerv Syst 2012, [Epub ahead of print].

5. Sgouros S, Malluci C, Walsh AR, Hockley AD: Long-term complications of hydrocephalus. Pediatr Neurosurg 1995, 23:127-132.

6. Odio C, McCracken GH Jr, Nelson JD: CSF shunt infections in pediatrics. A seven-year experience. Am J Dis Child 1984, 138:1103-1108.

7. Kulkarni AV, Drake JM, Lamberti-Pasculli M: Cerebrospinal fluid shunt infection: a prospective study of risk factors. J Neurosurg 2001, 94:195-201.

8. Piatt JH Jr, Carlson CV: A search for determinants of cerebrospinal fluid shunt survival: retrospective analysis of a 14-year institutional experience. Pediatr Neurosurg 1993, 19:233-242.

9. Vinchon M, Dhellemmes P: Cerebrospinal fluid shunt infection: risk factors and long-term follow-up. Childs Nerv Syst 2006, 22:692-697. 
10. Mangram AJ, Horna IP, Silver LC, Jarvis WR, Hospital Infection Control Practices Advisory Committee: Guidelines for prevention of surgical infection. Infect Control Hosp Epidemiol 1999, 20:247-280.

11. Renier D, Lacombe J, Pierre-Kahn A, Sainte-Rose C, Hirsch JF: Factors causing acute shunt infection. Computer analysis of 1174 operations. J Neurosurg 1984, 61:1072-1078.

12. Smith ER, Butler WE, Barker FG 2nd: In-hospital mortality rates after ventriculoperitoneal shunt procedures in the United States, 1998 to 2000: relation to hospital and surgeon volume of care. J Neurosurg 2004 100(Suppl 2):90-97.

13. Albright AL, Pollack IF, Adelson PD, Solot JJ: Outcome data and analysis in pediatric neurosurgery. Neurosurgery 1999, 45:101-106.

14. Baskin JJ, Manwaring KH, Rekate HL: Ventricular shunt removal: the ultimate treatment of the slit ventricle syndrome. J Neurosurg 1998, 88:478-484.

15. Cinalli G, Salazar C, Mallucci C, Yada JZ, Zerah M, Sainte-Rose C: The role of endoscopic third ventriculostomy in the management of shunt malfunction. Neurosurgery 1998, 43:1323-1327.

16. Longatti PL, Carteri A: Active singling out of shunt independence. Childs Nerv Syst 1994, 10:334-336

17. Lorber J, Pucholt $V$ : When is a shunt no longer necessary? An investigation of 300 patients with hydrocephalus and myelomeningocele: 11-22 year follow up. Z Kinderchir 1981, 34:327-329.

18. Talamonti G, D'Aliberti G, Collice M: Myelomeningocele: long-term neurosurgical treatment and follow-up in 202 patients. J Neurosurg 2007, 107(Suppl 5):368-386.

19. Di Rocco C, Massimi L, Tamburrini G: Shunts vs endoscopic third ventriculostomy in infants: are there different types and/or rates of complications? A review. Childs Nerv Syst 2006, 22:1573-1589

20. O'Brien DF, Javadpour M, Collins DR, Spennato P, Mallucci CL: Endoscopic third ventriculostomy: an outcome analysis of primary cases and procedures performed after ventriculoperitoneal shunt malfunction. J Neurosurg 2005, 103(5 Suppl):393-400.

21. Ogiwara H, Dipatri AJ Jr, Alden TD, Bowman RM, Tomita T: Endoscopic third ventriculostomy for obstructive hydrocephalus in children younger than 6 months of age. Childs Nerv Syst 2010, 26:343-347.

22. Fukuhara T, Vorster SJ, Luciano MG: Risk factors for failure of endoscopic third ventriculostomy for obstructive hydrocephalus. Neurosurgery 2000, 46:1100-1111

23. Naftel RP, Reed GT, Kulkarni AV, Wellons JC: Evaluating the Children's Hospital of Alabama endoscopic third ventriculostomy experience using the Endoscopic Third Ventriculostomy Success Score: an external validation study. J Neurosurg Pediatr 2011, 8:494-501.

24. Kulkarni AV, Drake JM, Kestle JR, Mallucci CL, Sgouros S, Constantini S, Canadian Pediatric Neurosurgery Study Group: Endoscopic third ventriculostomy vs cerebrospinal fluid shunt in the treatment of hydrocephalus in children: a propensity score-adjusted analysis. Neurosurgery 2010, 67:588-593.

25. Byard RW: Mechanisms of sudden death and autopsy findings in patients with Arnold-Chiari malformation and ventriculoatrial catheters. Am J Forensic Med 1996, 17:260-263.

26. Paulsen AH, Lundar T, Lindegaard KF: Twenty-year outcome in young adults with childhood hydrocephalus: assessment of surgical outcome, work participation, and health-related quality of life. J Neurosurg Pediatr 2010, 6:527-535

27. Resch B, Gedermann A, Maurer U, Ritschl E, Müller W: Neurodevelopmental outcome of hydrocephalus following intra-/periventricular hemorrhage in preterm infants: short- and long-term results. Childs Nerv Syst 1996, 12:27-33.

28. Jennett B, Snoek J, Bond MR, Brooks N: Disability after severe head injury: observations on the use of the Glasgow outcome scale. J Neurol Neurosurg Psychiat 1981, 44:285-293.

29. Kulkarni AV, Shams I: Quality of life in children with hydrocephalus: results from the Hospital for Sick Children, Toronto. J Neurosurg 2007, 107(Suppl 5):358-364.

30. Platenkamp M, Hanlo PW, Fischer K, Gooskens RH: Outcome in pediatric hydrocephalus: a comparison between previously used outcome measures and the hydrocephalus outcome questionnaire. J Neurosurg 2007, 107(1 Suppl):26-31.
31. Dalen K, Bruarøy S, Wentzel-Larsen T, Laegreid LM: Intelligence in children with hydrocephalus, aged 4-15 years: a population-based, controlled study. Neuropediatrics 2008, 39:146-150.

32. Dennis M, Fitz CR, Netley CT, Sugar J, Harwood-Nash DC, Hendrick EB, Hoffman HJ, Humphreys RP: The intelligence of hydrocephalic children. Arch Neurol 1981, 38:607-615.

33. Venkataramana NK, Mukundan CR: Evaluation of functional outcomes in congenital hydrocephalus. J Pediatr Neurosci 2011, 6:4-12.

34. Adams-Chapman I, Hansen NI, Stoll BJ, Higgins R, NICHD Research Network: Neurodevelopmental outcome of extremely low birth weight infants with posthemorrhagic hydrocephalus requiring shunt insertion. Pediatrics 2008, 121:e1167-e1177. doi:10.1542/peds.2007-0423.

35. Andersson S, Persson EK, Aring E, Lindquist B, Dutton GN, Hellström A: Vision in children with hydrocephalus. Dev Med Child Neurol 2006, 48:836-841.

36. Hoppe-Hirsch E, Laroussinie F, Brunet L, Sainte-Rose C, Renier D, Cinalli G, Zerah M, Pierre-Kahn A: Late outcome of the surgical treatment of hydrocephalus. Child's Nerv Syst 1998, 14:97-99.

37. Gupta N, Park J, Solomon C, Kranz DA, Wrensch M, Wu YW: Long-term outcomes in patients with treated childhood hydrocephalus. J Neurosurg 2007, 106(5 Suppl):334-339.

38. Proos LA, Dahl M, Ahlsten G, Tuvemo T, Gustafsson J: Increased perinatal intracranial pressure and prediction of early puberty in girls with myelomeningocele. Arch Dis Child 1996, 75:42-45.

39. Bourgeois M, Sainte-Rose C, Cinalli G, Maixner W, Malucci C, Zerah M, Pierre-Kahn A, Renier D, Hoppe-Hirsch E, Aicardi J: Epilepsy in children with shunted hydrocephalus. J Neurosurg 1999, 90:274-281.

40. Rekate HL, Kranz D: Headaches in patients with shunts. Semin Pediatr Neurol 2009, 16:27-30

41. Lacy M, Pyykkonen BA, Hunter SJ, Do T, Oliveira M, Austria E, Mottlow D, Larson E, Frim D: Intellectual functioning in children with early shunted posthemorrhagic hydrocephalus. Pediatr Neurosurg 2008, 44:376-378.

42. Oakes WJ: Long-tem outcome of hydrocephalus. Editorial J Neurosurg 2007, 106(Suppl 5):333.

43. Hanlo PW, Cinalli G, Vandertop WP, Faber JA, Bøgeskov L, Børgesen SE, Boschert J, Chumas P, Eder H, Pople IK, Serlo W, Vitzthum E: Treatment of hydrocephalus determined by the European Orbis Sigma Valve II survey: a multicenter prospective 5-year shunt survival study in children and adults in whom a flow-regulating shunt was used. J Neurosurg 2003, 99:52-57.

44. Persson EK, Hagberg G, Uvebrant P: Disabilities in children with hydrocephalus-a population-based study of children aged between four and twelve years. Neuropediatrics 2006, 37:330-336.

45. Xenos C, Sgouros S, Natarajan K, Walsh AR, Hockley A: Influence of shunt type on ventricular volume changes in children with hydrocephalus. J Neurosurg 2003, 98:277-383

46. Kestle J, Drake J, Milner R, Sainte-Rose C, Cinalli G, Boop F, Piatt J, Haines S, Schiff S, Cochrane D, Steinbok P, MacNeil N: Long-term follow-up data from the Shunt Design Trial. Pediatr Neurosurg 2000, 33:230-236.

47. Lindquist $B$, Persson EK, Fernell E, Uvebrant P: Very long-term follow-up of cognitive function in adults treated in infancy for hydrocephalus. Childs Nerv Syst 2011, 27:597-601.

48. Kokkonen J, Serlo W, Saukkonen AL, Juolasmaa A: Long-term prognosis for children with shunted hydrocephalus. Childs Nerv Syst 1994, 10:384-387.

49. Lumenta CB, Skotarczak U: Long-term follow-up in 233 patients with congenital hydrocephalus. Childs Nerv Syst 1995, 11:173-175.

50. Chi JH, Fullerton HJ, Gupta N: Time trends and demographics of deaths from congenital hydrocephalus in children in the United States: National Center for Health Statistics data, 1979 to 1998. J Neurosurg 2005, 103(Suppl 2):113-118.

51. Sainte-Rose C, Hoffmann HJ, Hirsch JF: Shunt failure. Concepts Pediatr Neurosurg 1989, 9:7-20.

52. Choux M, Genitori L, Lang D, Lena G: Shunt implantation: reducing the incidence of shunt infection. J Neurosurg 1992, 77:875-880.

53. Cochrane DD, Kestle JRW: The influence of surgical operative experience on the duration of first ventriculoperitoneal shunt function and infection. Pediatr Neurosurg 2003, 38:295-301.

54. lannelli A, Rea G, Di Rocco C: CSF shunt removal in children with hydrocephalus. Acta Neurochir (Wien) 2005, 147:503-507.

55. Hemmer R, Böhm B: Once a shunt, always a shunt? Dev Med Child Neurol 1976, 37(suppl):69-73. 
56. Kao CL, Yang TF, Wong TT, Cheng LY, Huang SY, Chen HS, Kao CL, Chan RC: The outcome of shunted hydrocephalic children. Zhonghua Yi Xue Za Zhi (Taipei) 2001, 64:47-53.

57. Heinsbergen I, Rotteveel J, Roeleveld N, Grotenhuis A: Outcome in shunted hydrocephalic children. Eur J Paediatr Neurol 2002, 6:99-107.

58. Tuli S, Tuli J, Drake J, Spears J: Predictors of death in pediatric patients requiring cerebrospinal fluid shunts. J Neurosurg 2004, 100(Suppl 5):442-446.

59. Persson EK, Anderson S, Wiklund LM, Uvebrant P: Hydrocephalus in children born in 1999-2002: epidemiology, outcome and ophthalmological findings. Childs Nerv Syst 2007, 23:1111-1118

60. Piatt JH Jr, Carlson CV: Hydrocephalus and epilepsy: an actuarial analysis. Neurosurgery 1996, 39:722-728.

61. Casey AT, Kimmings EJ, Kleinlugtebeld AD, Taylor WA, Harkness WF, Hayward RD: The long-term outlook for hydrocephalus in childhood. A ten-year cohort study of 155 patients. Pediatr Neurosurg 1997, 7:63-70.

62. Tuli S, Drake J, Lawless J, Wigg M, Lamberti-Pasculli M: Risk factors for repeated cerebrospinal shunt failures in pediatric patients with hydrocephalus. J Neurosurg 2000, 92:31-38.

63. Bryant MJ, McEniery J, Walker DG, Campbell R, Lister B, Sargent $P$, Withers TK, Baker J, Guazzo E, Rossato R, Anderson D, Tomlinson F: Preliminary study of shunt related death in paediatric patients. J Clin Neurosci 2004, 11:614-615.

64. Koch-Wiewrodt D, Wagner W: Success and failure of endoscopic third ventriculostomy in young infants: are there different age distributions? Childs Nerv Syst 2006, 22:1537-1541.

65. Appelgren T, Zetterstrand S, Elfversson J, Nilsson D: Long-term outcome after treatment of hydrocephalus in children. Pediatr Neurosurg 2010, 46:221-226

66. Boynton BR, Boynton CA, Merritt TA, Vaucher YE, James HE, Bejar RF: Ventriculoperitoneal shunts in low birth weight infants with intracranial hemorrhage: neurodevelopmental outcome. Neurosurgery 1986, 18:141-145.

67. James HE, Bejar R, Gluck L, Coen R, Merritt A, Mannino F, Bromberger P, Saunders B, Schneider $\mathrm{H}$ : Ventriculoperitoneal shunts in high risk newborns weighing under 2000 grams: a clinical report. Neurosurgery 1984, 15:198-202.

68. Vinchon M, Lapeyre F, Duquennoy C, Dhellemmes P: Early treatment of posthemorrhagic hydrocephalus in low-birth-weight infants with valveless ventriculoperitoneal shunts. Pediatr Neurosurg 2001, 35:299-304

69. Buxton N, Macarthur D, Mallucci C, Punt J, Vloeberghs M: Neuroendoscopy in the premature population. Childs Nerv Syst 1998, 14:649-652.

70. Lazareff JA, Peacock W, Holly L, Ver Halen J, Wong A, Olmstead C: Multiple shunt failures: an analysis of relevant factors. Childs Nerv Syst 1998, 14:271-275

71. Schoenbaum SC, Gardner P, Shillito J: Infections of cerebrospinal fluid shunts: epidemiology, clinical manifestations, and therapy. J Infect Dis 1975, 131:543-552.

72. Warf BC, Dagi AR, Kaaya BN, Schiff SJ: Five-year survival and outcome of treatment for postinfectious hydrocephalus in Ugandan infants. J Neurosurg Pediatr 2011, 8:502-508.

73. Quigley MR, Reigel DH, Kortyna R: Cerebrospinal fluid shunt infections. Report of 41 cases and a critical review of the literature. Pediatr Neurosci 1989, 15:111-120.

74. Vinchon M, Dhellemmes P: Hydrocephalus in Myelomeningocele: Shunts and Problems with Shunts. In The spina bifida: management and outcome. Edited by Ozek M, Cinalli G, Maixner WJ. Milan: Springer; 2008:215-224.

75. Hader WJ, Walker RL, Myles ST, Hamilton M: Complications of endoscopic third ventriculostomy in previously shunted patients. Neurosurgery 2008, 63(1 Suppl 1):ONS168-ONS174.

76. Hetherington R, Dennis M, Barnes M, Drake J, Gentili F: Functional outcome in young adults with spina bifida and hydrocephalus. Childs Nerv Syst 2006, 22:117-124.

77. Hunt GM, Oakeshot P, Kerry S: Link between the CSF shunt and achievement in adults with spina bifida. J Neurol Neurosurg Psychiatr 1999, 67:591-595.

78. Kulkarni AV, Drake JM, Rabin D, Dirks PB, Humphreys RP, Rutka JT: Measuring the health status of children with hydrocephalus by using a new outcome measure. J Neurosurg 2004, 101(Suppl 2):141-146.
79. Kulkarni AV, Hui S, Shams I, Donnelly R: Quality of life in obstructive hydrocephalus: endoscopic third ventriculostomy compared to cerebrospinal fluid shunt. Childs Nerv Syst 2010, 26:75-79.

80. Kramer U, Kanner AA, Siomin V, Harel S, Constantini S: No evidence of epilepsy following endoscopic third ventriculostomy: a short-term follow-up. Pediatr Neurosurg 2001, 34:121-123.

81. Gathura E, Poenaru D, Bransford R, Albright AL: Outcomes of ventriculoperitoneal shunt insertion in Sub-Saharan Africa. J Neurosurg Pediatr 2010, 6:329-335.

82. Vinchon M, Fichten A, Delestret I, Dhellemmes P: Shunt revision for asymptomatic failure: surgical and clinical results. Neurosurgery 2003 52:347-353.

83. O'Kane MC, Richards H, Winfield P, Pickard JD: The United Kingdom Shunt Registry. Eur J Pediatr Surg 1997, 7(Suppl 1):56.

84. Chern J, Macias CG, Jea A, Curry DJ, Luerssen TG, Whitehead WE: Effectiveness of a clinical pathway for patients with cerebrospinal fluid shunt malfunction. J Neurosurg Pediatr 2010, 6:318-324.

85. Buxton N, Punt J: Failure to follow patients with hydrocephalus shunts can lead to death. Br J Neurosurg 1998, 12:399-401.

86. Hockley AD, Walsh AR, Sgouros S: Follow-up of children with shunted hydrocephalus (letter). Br J Neurosurg 1996, 10:525.

87. Kimmings E, Kleinlugtebeld A, Casey AT, Hayward RD: Does the child with shunted hydrocephalus require long-term neurosurgical follow-up? $\mathrm{Br} J$ Neurosurg 1996, 10:77-81.

88. Colak A, Albright AL, Pollack IF: Follow-up of children with shunted hydrocephalus. Pediatr Neurosurg 1997, 27:208-210.

89. Tuli S, O'Hayon B, Drake J, Clarke M, Kestle J: Change in Ventricular Size and Effect of Ventricular Catheter Placement in Pediatric Patients with Shunted Hydrocephalus. Neurosurgery 1999, 45:1329-1335.

90. Steinbok P, Boyd M, Flodmark CO, Cochrane DD: Radiographic imaging requirements following ventriculoperitoneal shunt procedures. Pediatr Neurosurg 1995, 22:141-146.

91. Iskandar BJ, Sansone JM, Medow J, Rowley HA: The use of quick-brain magnetic resonance imaging in the evaluation of shunt-treated hydrocephalus. J Neurosurg 2004, 101(Suppl 2):147-151.

92. Vassilyadi M, Tataryn ZL, Alkherayf F, Udjus K, Ventureyra EC: The necessity of shunt series. J Neurosurg Pediatr 2010, 6:468-473.

93. Drake J, Chumas P, Kestle J, Pierre-Kahn A, Vinchon M, Brown J, Pollack IF, Arai $\mathrm{H}$ : Late rapid deterioration after endoscopic third ventriculostomy: additional cases and review of the literature. J Neurosurg 2006, 105(Suppl 2):118-126.

94. Mohanty A, Vasudev MK, Sampath S, Radhesh S, Sastry Kolluri VR: Failed endoscopic third ventriculostomy in children: management options. Pediatr Neurosurg 2002, 37:304-309.

95. Vinchon $M$, Dhellemmes $P$ : The transition from child to adult in neurosurgery. Adv Tech Stand Neurosurg 2007, 32:3-24.

doi:10.1186/2045-8118-9-18

Cite this article as: Vinchon et al:: Pediatric hydrocephalus outcomes: a review. Fluids and Barriers of the CNS 2012 9:18.

\section{Submit your next manuscript to BioMed Central and take full advantage of:}

- Convenient online submission

- Thorough peer review

- No space constraints or color figure charges

- Immediate publication on acceptance

- Inclusion in PubMed, CAS, Scopus and Google Scholar

- Research which is freely available for redistribution 